\title{
Analisis Efektifitas Penggunaan Auto Scaner Barcode pada Inner Box Menggunakan Metode Pengujian Validitas dan Reliabilitas (Studi Kasus: PT. Duta Nichirindo Pratama)
}

\author{
Ade Sumaedi1)*, Makhsun ${ }^{1), 2)}$, Achmad Hindasyah'1), 2) \\ 1)Program Pasca Sarjana (S2) Magister Komputer, Program Studi Teknik Informatika Sekolah Tinggi Manajemen \\ Informatika dan Komputer Eresha. \\ 2)Badan Tenaga Nuklir Nasional \\ ^Email: adesumaedi87@gmail.com
}

Info Artikel

\section{Kata Kunci :}

scaner barcode, visual basic.Net, arduino, validitas dan reliabilitas

\section{Keywords :}

scaner barcode, visual basic.Net, arduino, validitas and reliabilitas

\section{Tanggal Artikel}

Dikirim : 24 Oktober 2020

Direvisi : 02 November 2020

Diterima : 30 November 2020

\begin{abstract}
Abstrak
Inner boxmerupakan salah satu child partyang digunakan untuk proses packaging product di PT. Duta Nichirindo Pratama yang memproduksi bermacam-macam filter seperti filter udara, filterbahan bakar, filteroli dan cabin filter. Inner boxyang dilengkapi dengan barcode bertujuan untuk mempermudah perusahaan dan konsumen dalam mendeteksi jumlah produk, nomor produk dan jenis produk yang dikemas pada inner boxagar tidak terjadi kesalahan dalam penggunaannya. Dalam hal ini PT. Duta Nichirindo Pratama merancang suatu sistem untuk pengecekan barcode pada inner box secara otomatis yang berbasis komputasi seperti Visual Basic.Net, Arduino dan diagram Unified Modeling Language (UML). Sistem perancangan ini dimulai Juni 2019 pada line assembling, dari hasil perbaikan pengecekan barcode secara otomasis yang sudah berjalan maka perlu adanya penelitian terkait kenyamanan dan ke efektifitasan karyawan dengan mengukur tingkat validitas (nilai $r$ hitung $>r$ tabel) dan reabilitas (nila alpha $>0,60$ ) penggunaan auto scaner barcode pada inner box. Dimana hasil pengujian validitas adalah nilai $r$ hitung untuk auto scaner barcode dapat memisahkan barcode yang No Good (NG) secara otomatis adalah 0,678 lebih besar dari $r$ table $\mathrm{df}=(\mathrm{N}-2=10-$ $2=8=0,6319$ ) dan hasil pengujian reliability adalah nilai Cronbach's A/pha (nila alpha) yaitu 4,157 lebih besar dari 1,00, jadi implementasi pengecekan barcode secara otomatis dinyatakan efektif (reliabilitas sangat tinggi).
\end{abstract}

\section{Abstarct}

Inner box is one of the child parts used for product packaging process at PT. Duta Nichirindo Pratama which produces various filters such as air filters, fuel filters, oil filters and cabin filters. The inner box, which is equipped with a barcode, aims to make it easier for companies and consumers to detect the number of products, product numbers and types of products packaged in the inner box so that there are no errors in their use. In this case PT. Duta Nichirindo Pratama designed a computation-based automatic barcode checking system for inner boxes such as Visual Basic.Net, Arduino and Unified Modeling Language (UML) diagrams. This design system starts in June 2019 at line assembling, from the results of improvements in automatic barcode checking that have been running, it is necessary to have research related to employee comfort and effectiveness by measuring the level of validity ( $r$ count $>r$ table) and reliability (alpha value $>0,60$ ) use auto barcode scanner on the inner box. Where the results of the validity test are the calculated $r$ value for the auto scanner barcode that can separate the No Good (NG) barcode automatically is 0.678 which is greater than the $r$ table $d f=(N-$ $2=10-2=8=0.6319$ ) and the test results reliability is the Cronbach's Alpha value (alpha value), which is 4.157, greater than 1.00, so the implementation of barcode checking is automatically declared effective (very high reliability). 


\section{PENDAHULUAN}

PT. Duta Nichirindo Pratama merupakan perusahaan yang bergerak dalam bidang Filter Autoparts Manufacture yang sangat berkomitmen dalam menjaga kualitas produk dan menjaga kepercayaan konsumen, dari hal tersebut perusahaan menjalankan perbaikan secara berkelanjutan dengan mengimplementasikan sistem ISO 9001:2015 (ISO Sistem Manajemen Mutu). Awal bulan Juli 2019 perusahaan melakukan perbaikan sistem pengecekan barcode pada inner box secara otomatis (scaner barcode auto system computation) pada line assembling production, yang sebelumnya pengecekan barcode secara manual (visual check). Perbaikan tersebut bertujuan untuk mempermudah pengecekan barcode dan meminimalisir terjadinya kesalahan penggunaan inner boxyang similiar, dalam proses implementasi pada perbaikan tersebut komitmen dan konsistensi karyawan (operator produksi) sangatlah penting. Maka dari hal ini perlu adanya pengujian terhadap kenyamanan dan keefektifitasan karyawan terkait penggunaan auto scaner barcode dengan cara menganalisa kuisioner yang diberikan kepada karyawan, seperti Tabel 1.

Tabel 1. Kuisioner analisa implementasi penggunaan scaner barcode auto system computation

\begin{tabular}{clc}
\hline No. & \multicolumn{1}{c}{$\begin{array}{c}\text { Uraian Kuisioner Pernyataan Implementasi Penggunaan Auto Scaner } \\
\text { Barcode pada Inner Box (Kemasan Produk) }\end{array}$} & Simbol \\
\hline 1 & Dapat Mengetahui Kesalahan Pada Label Barcode & $\mathrm{P} 1$ \\
2 & Dapat Memunculkan Master Barang dan Memunculkan Stock Barang & $\mathrm{P} 2$ \\
3 & Dapat Memunculkan Laporan dan Menampilkan Qty & $\mathrm{P} 3$ \\
4 & Dapat Memberikan Tanda Peringatan Apabila ada Kesalahan Barcode & $\mathrm{P} 4$ \\
5 & Dapat Membaca Barcode Dengan Cepat & $\mathrm{P} 5$ \\
6 & Dapat Mengindentifikasi Kode Barcode & $\mathrm{P} 6$ \\
7 & Dapat Menampilkan Jumlah Produksi Yang OK & $\mathrm{P} 7$ \\
8 & Dapat Menampilkan Jumlah Produksi Yang No Good (NG) & $\mathrm{P} 8$ \\
9 & Dapat Mengurangi Kesalahan Pada Barcode Inner Box & $\mathrm{P} 9$ \\
10 & Dapat Memisahkan Barcode Yang No Good (NG) Secara Otomatis & $\mathrm{P} 10$ \\
\hline
\end{tabular}

\section{METODE PENELITIAN}

Sementara yang saat ini masih berjalan operator produksi pada bagian assembling terpaku pada box yang berada diatas mesin conveyor dan tanpa memperhatikan box tersebut sesuai dengan item/barang yang ada pada produksi hari tersebut, dan untuk alat scaner belum ada. Sedangkan operator cenderung memperhatikan apa yang ada dimesin conveyor yang sedang berjalan, karena jika tidak maka barang/product akan menumpuk di mesin tersebut. Beberapa alat-alat pendukung perancangan dalam pembuatan scaner barcode outo system computation, meliputi: Arduino ATmega2560, Scaner Barcode, Visual Basic,Net, dan Unified Modelling Language (UML) [8]. Perhitungan pengujian Validitas dan Reliabilitas [5] adalah metode analisa untuk menentukan/mengukur tingkat efektfitas dalam mengimplemenntasi penggunaan scaner barcode outo system computation.

\subsection{Pengujian Validitas dan Reliabilitas}

Validitas adalah pengujian yang digunakan untuk mengukur instrumen/kuisioner penelitian apakah valid atau tidaknya suatu pengujian tersebut. Valid berarti instrumen yang digunakan dapat mengukur yang hendak diukur [1], berikut ini adalah rumus perhitungannya:

$$
r_{x y}=\frac{n \sum_{i=1}^{n} x_{i} y_{i}-\sum_{i=1}^{n} x_{i} \sum_{i=1}^{n} y_{i}}{\sqrt{\left(n \sum_{i=1}^{n} x_{i}^{2}-\left(\sum_{i=1}^{n} x_{i}\right)^{2}\right)}-\left(n \sum_{i=1}^{n} y_{i}^{2}-\left(\sum_{i=1}^{n} y_{i}\right)^{2}\right)}
$$

Keterangan:

$r_{x y}$ adalah koefisien korelasi antara variable $X$ dan variable $Y$ 
$X_{i}$ adalah nilai data ke-i untuk kelompok variable $X$

$y_{i}$ adalah nilai data ke-i untuk kelompok variable $Y$

$\mathrm{n}$ adalah banyak data

Bandingkan nilai koefisien validitas hasil langkah-2 dengan nilai koefisien korelasi Pearson / tabel Pearson ( $\left.\mathrm{r}_{\text {tabel }}\right)$ pada taraf signifikansi $\alpha$ (biasanya dipilih 0.05 ) dan $n=$ banyaknya data yang sesuai. Kriteria: Instrumen valid, jika $r_{\text {hitung }} \geq r_{\text {tabel }}$ Instrumen tidak valid, jika $r_{\text {hitung }}<r_{\text {tabel }}$ [2].

Reliabilitas adalah pengujian yang digunakan untuk mengukur konsistensi instrumen/kuisioner penelitian. Reliabilitas berarti instrumen/kuisioner yang dapat mengukur hal yang diukur secara konsisten sedangkan tidak reliabel berarti instrumen tidak konsisten, dimana untuk kategori perhitungan nilai standard reabilitas koefisien [3], yaitu:

$0,80<$ CrAlfa $\leq 1,00$ reliabilitas sangat tinggi (reliabel/konsisten)

$0,60<$ CrAlfa $\leq 0,80$ reliabilitas tinggi (reliabel/konsisten)

$0,40<$ CrAlfa $\leq 0,60$ reliabilitas sedang (tidak reliabel/ tidak konsisten)

$0,20<$ CrAlfa $\leq 0,40$ reliabilitas rendah (tidak reliabel/tidak konsisten)

$-1,60 \leq$ CrAlfa $\leq 0,20$ reliabilitas sangat rendah (tidak reliabel/tidak konsisten)

berikut ini adalah rumus perhitungannya:

$$
\begin{gathered}
S^{2}=\frac{n \sum x^{2}-\left(\sum x\right)^{2}}{n(n-1)} \\
\text { CrAlpha }=\left(\frac{k}{k-1}\right)\left(1-\frac{\sum s^{2} p}{s^{2} t}\right)
\end{gathered}
$$

Keterangan:

$\mathrm{k}$ adalah jumlah pernyataan instrumen/kuisioner $\mathrm{n}$ adalah jumlah responden

$\Sigma s^{2} p$ adalah total dari varian butir pernyataan $\quad x$ adalah jumlah dari nilai kuisioner

$s^{2} t$ adalah varian dari total nilai responden

\subsection{Langkah-Langkah Penelitian}

\subsubsection{Metode Pengumpulan Data}

Agar dapat mengumpulkan data-data yang baik maka penulis menggunakan metode:

1. Metode Observasi

Dengan metode ini penulis langsung terjun ke lapangan untuk mengetahui permasalahan apa yang dihadapi dalam implementasi penggunaan scaner barcode outo system computation

2. Metode Interview

Dengan metode ini juga penulis mencoba mencari keterangan dari beberapa karyawan dengan berbicara mengenai masalah atau kendala apa saja yang terjadi.

3. Study Pustaka

Penulis akan mencari dari berbagai sumber mulai dari buku-buku hingga yang lainnya.

\subsubsection{Metode Rancangan}

Ada beberapa pembuatan rancangan yang sudah diimplementasikan pada penggunaan scaner barcode outo system computation, seperti:

1. Pembuatan sistem yang baru

Dalam pembuatan sistem ini mengunakan metode rancangan Unified Modelling Language (UML).

2. Penggunaan database pemograman

Dalam pembuatan database dimulai dengan rancangan tabel dengan menggunakan sql server dikarenakan dengan menggunakan sql server untuk penyimpanan datanya tidak terbatas. 
3. Penggunaan bahasa pemograman

Untuk bahasa pemograman menggunakan visual studio vb.net dikarenakan lebih cocok (compatible) dengan sistem operasi pada saat ini.

4. Pembuatan desain system

Dalam perancangan sistem aplikasi diperlukan desain form, mulai dari login, menu utama, menu tambahan sampai dengan menu laporan.

\subsubsection{Metode Analisa}

Untuk metode analisa penulis menggunakan metode perhitungan pengujian validitas dan reliabilitas [9] untuk mengukur tingkat konsistensi karyawan (operator) dalam mengimplementasikan hasil perbaiakan scaner barcode outo system computation.

\section{HASIL DAN PEMBAHASAN}

\subsection{Implementasi Penggunaan Scaner Barcode Auto System Computation}

Dalam implementasi pembuatan dan penggunaan auto scaner barcode ini adalah penggabungan antara perangkat keras (hardware) dengan perangkat lunak (software). Beberapa perangkat yang digunakan dalam pembuatan auto scaner barcode, seperti: Arduino DF UNO / UNO [4], Barcode scanner [6], Buzzer, Pendorong, Relay, Personal Computer (PC) dirakit menjadi satu-kesatuan perancangan sistem komuter. Berikut ini adalah alur proses kerja auto scaner barcode Gambar 1, yaitu:

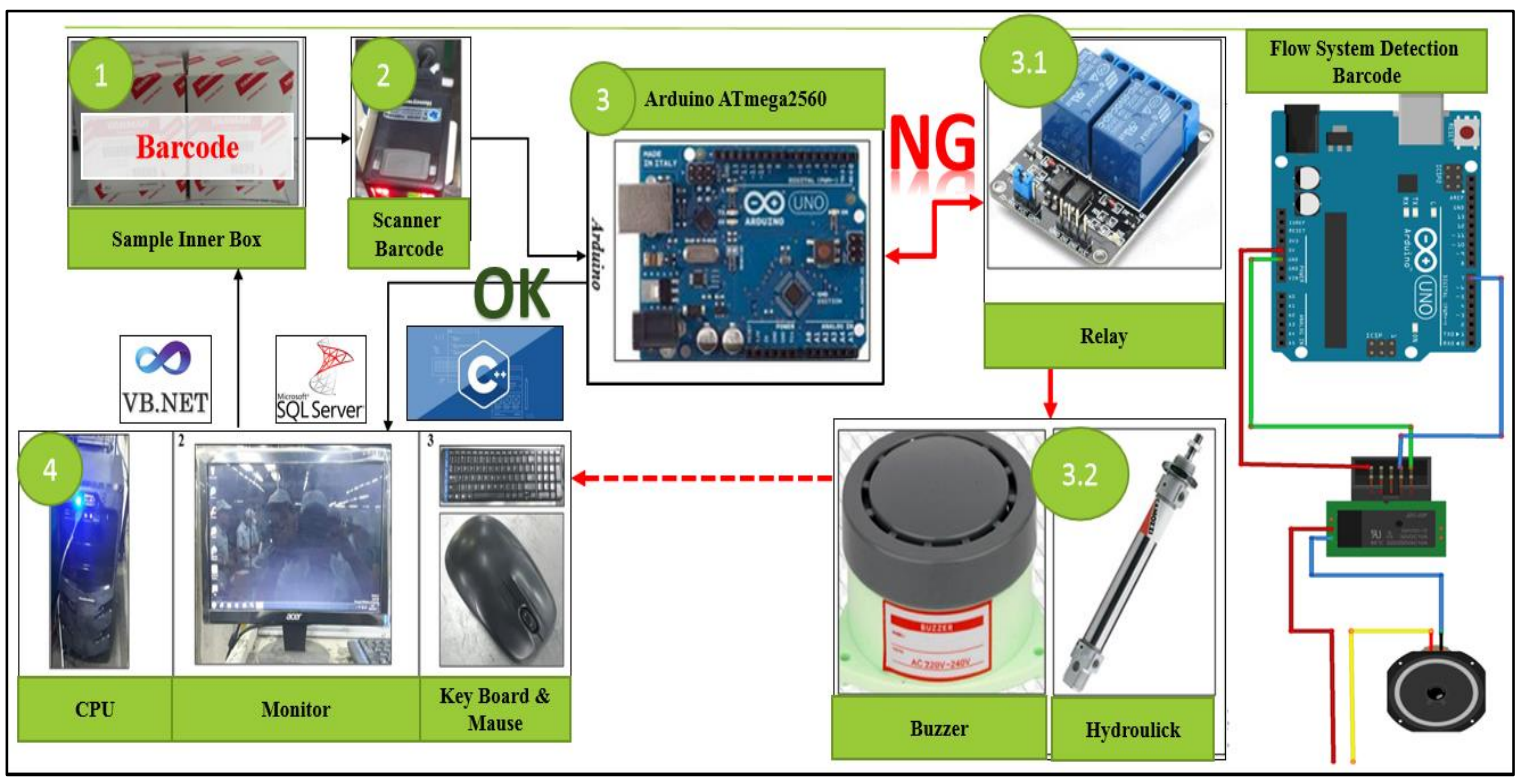

Gambar 1. Proses Kerja Auto Scaner Barcode

Berikut ini adalah penjelasan dari gambar alur proses kerja auto scaner barcode diatas sesuai nomor dan cara kerjanya, yaitu:

1. No.1 adalah Sample inner boxyang sudah tertempel barcode.

2. No. 2 adalah alat scaner barcodeyang berfungsi untuk membaca barcode.

3. No. 3 adalah microcontroller arduino yang berfungsi untuk memerintahkan pembacaan benar dan salahnya barcode. Apabila barcodetersebut benar sesuai standard, maka microcontroller arduino akan menyambungkan ke komputer dengan tampilan $O K$, namun apabila barcode tersebut tidak sesuai maka microcontroller arduino akan memerintahkan ke relay, hydroulick, buzzerdan komputer dengan tampilan NG.

4. No. 3.1 adalah Relayyang berfungsi untuk otomatisasi saklar (on/off) pengatur hydroulick dan buzzer 
5. No. 3.2 adalah hydroulick dan buzzer yang berfungsi sebagai otomatisasi apabila terjadi kesalahan pada pembacaan barcode, buzzerakan berbunyi dan hydroulick akan mendorong inner boxyang berada di conveyor untuk dipisahkan.

6. No. 4 adalah sistem komputasi (sistem pemograman: VB.NET, SQL Server dan bahasa $\mathrm{C}_{++}$) yang berfungsi sebagai penyimpanan data seperti: laporan produksi yang meliputi laporan pengecekan barcode per-item, laporan pengecekan barcode perhari, tampilan laporan OKdan NG barcode.

\subsection{Trial Auto Scaner Barcode}

Yang melatar belakangi dari proses Trial ini adalah adanya perbaikan pada proses produksi line assembling yaitu terkait Implementasi sistem pengecekan scan barcode pada inner box yang sebelumnya proses pengecekan manual (visual check) menjadi auto scaner barcode (otomatisasi komputasi). Berikut ini adalah hasil trial yang sudah dilakukan untuk mengukur tingkat ke efektifitasan proses auto scaner barcodedan beberapa perancangan yang digunakan dalam proses trial.

1. Perancangan basis data

Pada rancangan basis data ini akan diterangkan mengenai pengelolaan data-data pada sistem, sistem tersebut memerlukan beberapa tabel untuk digunakan untuk menyimpan data yang dibutuhkan.

2. Rancangan master data

Dalam rancangan master data ini terdapat beberapa master data saja di karenakan hanya sebagai informasi data barang dan penyimpan data produksi saja. Berikut penjelasan untuk tabel-tabel dalam menu master data:

a. Data barang

Data barang merupakan data yang berisi mengenai informasi nama, parts number, parts name, kode barcode serta gambar box.

Yang memimiliki atribut $\quad$ : kd_partno, kd_partname, kd_barco, pt

Nama Tabel : tbl_barang

Primary Key : none

Media : harddsik

b. Data hasil

Data hasil merupakan data yang berisi informasi mengenai hasil dari pada produksi yang berisikan berapa banyak produksi OK dan NG barcode.

Yang memiliki atribut : kd_barco, tgl, ok_barco, ng_barco

Nama Tabel : : tbl_hasil

Primary key : :kd_barcode

Media : harddisk

c. Barcode

Form barcode berisi aktifitas mengenai produksi yang berjalan, dimana di form ini adalah form utama dalam aplikasi yang direncanakan, yang berisikan tentang jumlah produksi yang $O K$ dan jumlah produksi yang $N G$.

d. Menu laporan

Rancangan laporan data peoduksi ini juga dibuat gambaran mengenai pengelompokan data menurut periode yang diharapkan bagi pengguna sistem. Pengelompokan data ini dimaksudkan untuk mempermudah proses analisis data pada waktu-waktu tertentu. Menu laporan ini seperti pada Gambar 2.

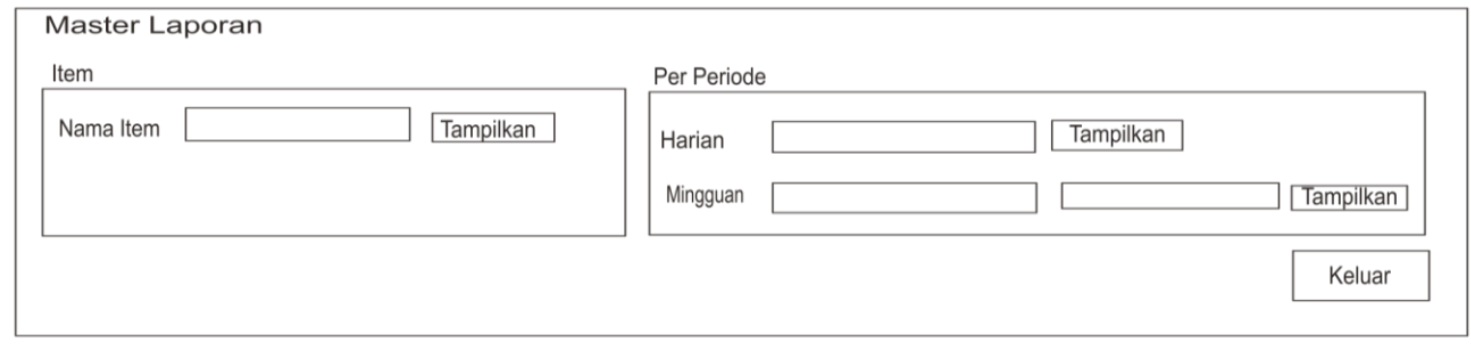

Gambar 2. Rancangan Form Laporan

Setelah dilakukan perbaikan pendeteksi kesalahan barcode [7] pada inner box, peneliti melakukan evaluasi pada hasil perbaikan tersebut untuk melihat efektifitas hasil implementasi dengan cara melakukan trial langsung pada 
operator. Pengujian dilakukan pada software maupun hardware pendukung untuk memberikan hasil yang diinginkan dan berfungsi dengan baik, mulai dari input maupun output. Proses trial ini sangat penting, karena sebagai acuan proses produksi dalam mengimplementasi auto scaner barcode. Berikut ini adalah data hasil tria/penggunaan master data, seperti Tabel 1.

Tabel 2. Trial Auto Scaner Barcode pada Line Assembling

\begin{tabular}{|c|c|c|c|c|c|}
\hline $\begin{array}{c}\text { No } \\
\text {. }\end{array}$ & $\begin{array}{c}\text { Sekenari } \\
0 \\
\text { Pengujia } \\
n \\
\end{array}$ & Test Case (Picture) & $\begin{array}{l}\text { Hasil Yang } \\
\text { Diharapkan }\end{array}$ & Hasil Pengujian (Picture) & $\underset{\mathbf{n}}{\text { Kesimpula }}$ \\
\hline 1. & $\begin{array}{l}\text { Input } \\
\text { kode } \\
\text { barcode } \\
\text { pada field } \\
\text { barcode } \\
\text { utama }\end{array}$ & 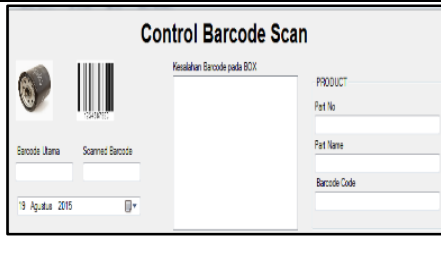 & $\begin{array}{l}\text { Otomatis } \\
\text { semua field } \\
\text { pada kolom } \\
\text { Product terisi }\end{array}$ & 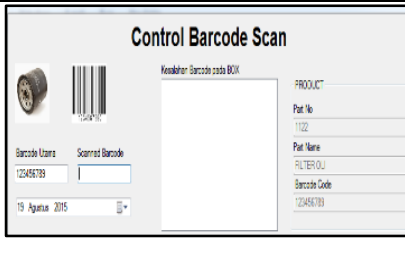 & Valid \\
\hline 2. & $\begin{array}{l}\text { Input } \\
\text { kode } \\
\text { barcode } \\
\text { pada field } \\
\text { barcode } \\
\text { utama } \\
\end{array}$ & 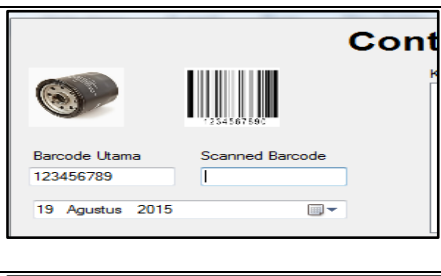 & $\begin{array}{l}\text { Sistem akan } \\
\text { memunculka } \\
\mathrm{n} \text { qty OK }\end{array}$ & 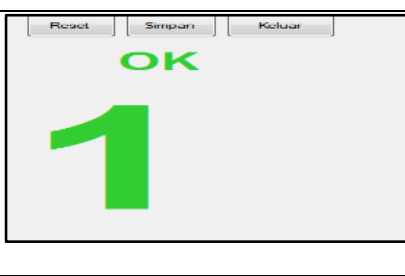 & Valid \\
\hline 3. & $\begin{array}{l}\text { Input } \\
\text { kode } \\
\text { barcode } \\
\text { pada field } \\
\text { barcode } \\
\text { utama }\end{array}$ & 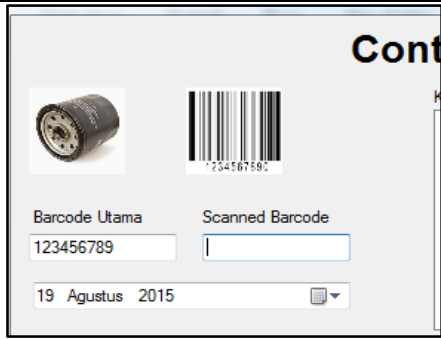 & $\begin{array}{l}\text { Sistem akan } \\
\text { memunculka } \\
\text { n qty NG jika } \\
\text { tidak sesui } \\
\text { dengan field } \\
\text { barcode } \\
\text { utama }\end{array}$ & 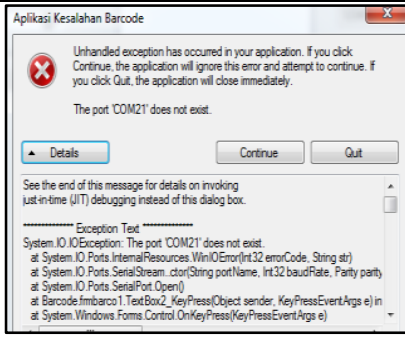 & $\begin{array}{l}\text { Tidak Valid } \\
\text { ( USB } \\
\text { untuk } \\
\text { arduino } \\
\text { tidak } \\
\text { terpasang ) }\end{array}$ \\
\hline 4. & $\begin{array}{l}\text { Input } \\
\text { kode } \\
\text { barcode } \\
\text { pada field } \\
\text { barcode } \\
\text { utama }\end{array}$ & \begin{tabular}{|l|l|} 
Aplikasi Kesalahan Barcode & \\
& \\
&
\end{tabular} & $\begin{array}{l}\text { Sistem akan } \\
\text { memunculka } \\
\text { n qty NG jika } \\
\text { tidak sesui } \\
\text { dengan field } \\
\text { barcode } \\
\text { utama }\end{array}$ & $\mathrm{OK}$ & Valid \\
\hline 5. & $\begin{array}{l}\text { Kode } \\
\text { barcode } \\
\text { tidak } \\
\text { sesuai }\end{array}$ & 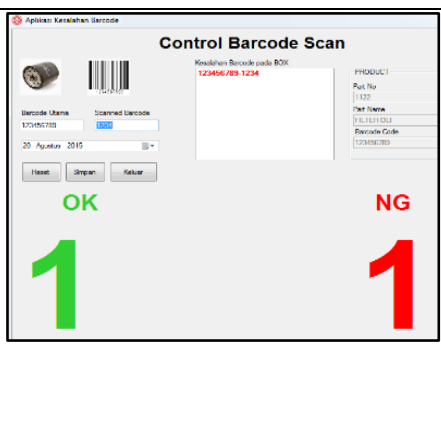 & $\begin{array}{l}\text { Sistem } \\
\text { memunculka } \\
\mathrm{n} \quad \text { qty } N G \\
\text { maka box } \\
\text { akan } \\
\text { terdorong } \\
\text { dan } \\
\text { membunyika } \\
\text { n buzzer }\end{array}$ & 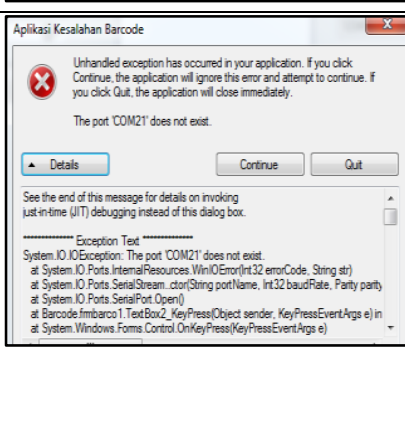 & $\begin{array}{l}\text { Tidak Valid } \\
\text { ( USB } \\
\text { untuk } \\
\text { arduino } \\
\text { tidak } \\
\text { terpasang ) }\end{array}$ \\
\hline
\end{tabular}




\begin{tabular}{|c|c|c|c|c|c|}
\hline No & $\begin{array}{l}\text { Sekenari } \\
\text { o } \\
\text { Pengujia } \\
\text { n }\end{array}$ & Test Case (Picture) & $\begin{array}{l}\text { Hasil Yang } \\
\text { Diharapkan }\end{array}$ & Hasil Pengujian (Picture) & $\begin{array}{l}\text { Kesimpula } \\
\text { n }\end{array}$ \\
\hline 6. & $\begin{array}{l}\text { Kode } \\
\text { barcode } \\
\text { tidak } \\
\text { sesuai }\end{array}$ & 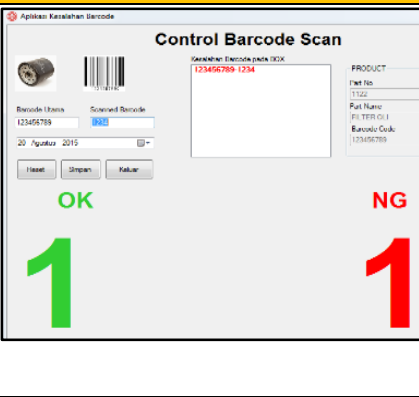 & $\begin{array}{l}\text { Sistem } \\
\text { memunculka } \\
\mathrm{n} \quad \text { qty NG } \\
\text { maka box } \\
\text { akan } \\
\text { terdorong } \\
\text { dan } \\
\text { membunyika } \\
\mathrm{n} \text { buzzer }\end{array}$ & & Valid \\
\hline 7. & $\begin{array}{l}\text { Simpan } \\
\text { control } \\
\text { barcode } \\
\text { scan }\end{array}$ & 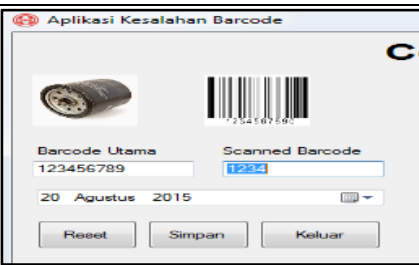 & $\begin{array}{l}\text { Sistem akan } \\
\text { menyimpan } \\
\text { ke database } \\
\text { dan muncul } \\
\text { pesan } \\
\text { "simpan" }\end{array}$ & 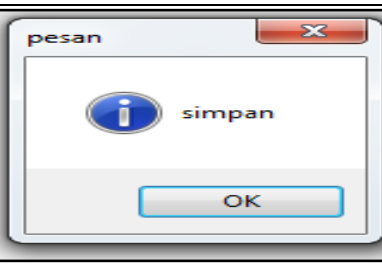 & Valid \\
\hline
\end{tabular}

Sementara yang saat ini masih berjalan operator produksi terpaku pada boxyang berada diatas mesin conveyor dan tanpa memperhatikan box tersebut sesuai dengan item/barang yang ada pada produksi hari tersebut, dan untuk alat scanner sudah ada namun tidak maksimal karena operator cenderung memperhatikan apa yang ada dimesin conveyoryang sedang berjalan, karena jika tidak maka barang/product akan menumpuk di mesin tersebut berawal dari masalah tersebut maka akan menerapkan sebuah aplikasi pendeteksi barcode secara otomatis. Dari hasil trial pada Tabel. 2 pada No. 1, 2, 4, 6 dan 7 dikatakan vilid karena sudah sesuai dengan hasil yang diharapkan oleh perusahaan, sedangkan pada No. 3 dan 5 dikatakan tidak vailid karena tidak sesuai, namun hal tersebut bukan menjadi kendala besar dalam perbaikan yang sudah dilakukan karena problem yang terjadi adalah kekeliruan dalam proses setting awal.

\subsection{Uji Validasi dan Reliabilitas Implementasi Penggunaan Auto Scaner Barcode pada Line Assembling}

Diharapkan dengan adanya aplikasi auto scaner barcode pada line assembling dapat mencegah terjadinya kesalahan dalam penempatan produk pada box, sehingga tidak ada lagi keluhan dari pelanggan. Berikut ini adalah jawaban dari pertanyaan-pertanyaan yang telah diajukan oleh penulis kepada karyawan, seperti pada Tabel 3.

Tabel 3. Jawaban Kuisioner Operator Terkait Implementasi Auto Scaner Barcode

\begin{tabular}{|c|c|c|c|c|c|c|c|c|c|c|c|c|}
\hline \multicolumn{13}{|c|}{ ANALISA KEBUTUHAN IMPLEMENTASI PENGGUNAAN AUTO SCANER BARCODE PADA INNER BOX } \\
\hline \multirow{2}{*}{ NO } & \multirow{2}{*}{$\begin{array}{l}\text { OPERATOR } \\
\text { (OP) }\end{array}$} & \multicolumn{11}{|c|}{ KUISIONER } \\
\hline & & P1 & P2 & P3 & P4 & P5 & P6 & P7 & P8 & P9 & P10 & TOTAL \\
\hline 1 & OP1 & 4 & 4 & 4 & 4 & 4 & 2 & 3 & 3 & 4 & 4 & 36 \\
\hline 2 & OP2 & 4 & 3 & 4 & 3 & 3 & 4 & 4 & 3 & 3 & 4 & 35 \\
\hline 3 & OP3 & 4 & 3 & 4 & 4 & 4 & 4 & 3 & 4 & 4 & 3 & 37 \\
\hline 4 & OP4 & 4 & 4 & 3 & 4 & 4 & 3 & 4 & 3 & 4 & 2 & 35 \\
\hline 5 & OP5 & 4 & 4 & 2 & 4 & 4 & 3 & 3 & 4 & 4 & 4 & 36 \\
\hline 6 & OP6 & 4 & 4 & 3 & 4 & 4 & 3 & 3 & 2 & 4 & 3 & 34 \\
\hline 7 & OP7 & 4 & 4 & 4 & 4 & 3 & 4 & 4 & 4 & 4 & 4 & 39 \\
\hline 8 & OP8 & 3 & 3 & 4 & 3 & 2 & 3 & 3 & 4 & 4 & 2 & 31 \\
\hline 9 & OP9 & 4 & 4 & 4 & 4 & 3 & 4 & 4 & 3 & 4 & 4 & 38 \\
\hline \multirow[t]{2}{*}{10} & OP10 & 4 & 4 & 4 & 4 & 3 & 3 & 4 & 2 & 3 & 3 & 34 \\
\hline & TOTAL & 39 & 37 & 36 & 38 & 34 & 33 & 35 & 32 & 38 & 33 & 355 \\
\hline
\end{tabular}


Dari uraian tersebut diatas maka penulis mengajukan altrenatif pemecahan kendala tersebut dengan:

1. Melakukan observasi proses untuk menganalisa tingkat kesulitan pada operator.

2. Distribusi formulir kuisoner terkait aktual penggunaan auto scaner barcode, sampling hanya 10 orang atau $80 \%$ dari total karyawan yang bekerja di line assembling

3. Ketentuan skor kuisioner yang diberikan untuk pertanyaan tersebut yaitu; Sangat Tidak Setuju (skor 1), Tidak Setuju (skor 2), Setuju (skor 3), dan Sangat Setuju (skor 4).

Setelah mendapatkan jawaban dari pertanyan-pertanyaan kuisioner yang diisi oleh karyawan, selanjutnya dilakukan pengujian Validasi dan Reliabilitas.

1. Perhitungan penentuan validitas

Berikut ini adalah contoh perhitungan pengujian validitas P5 (Dapat Membaca Barcode Dengan Cepat) seperti pada Tabel 5.

Tabel 4. Contoh Perhitungan Pengujian Validitas P5

\begin{tabular}{ccccccc}
\hline NO & OPERATOR (OP) & $\begin{array}{c}\text { P1 } \\
(\mathbf{X})\end{array}$ & $\begin{array}{c}\text { TOTAL } \\
(\mathbf{Y})\end{array}$ & $\mathbf{X}^{\mathbf{2}}$ & $\mathbf{Y}^{2}$ & $\mathbf{X Y}$ \\
\hline 1 & OP1 & 4 & 35 & 16 & 1225 & 140 \\
2 & OP2 & 3 & 34 & 9 & 1156 & 102 \\
3 & OP3 & 3 & 35 & 9 & 1225 & 105 \\
4 & OP4 & 3 & 35 & 9 & 1225 & 105 \\
5 & OP5 & 4 & 37 & 16 & 1369 & 148 \\
6 & OP6 & 4 & 35 & 16 & 1225 & 140 \\
7 & OP7 & 3 & 34 & 9 & 1156 & 102 \\
8 & OP8 & 3 & 34 & 9 & 1156 & 102 \\
9 & OP9 & 4 & 36 & 16 & 1296 & 144 \\
10 & OP10 & 3 & 34 & 9 & 1156 & 102 \\
\hline & TOTAL & $\mathbf{3 4}$ & $\mathbf{3 4 9}$ & $\mathbf{1 1 8}$ & $\mathbf{1 2 1 8 9}$ & $\mathbf{1 1 9 0}$ \\
\hline
\end{tabular}

Berikut ini adalah contoh perhitungan validitas konsisitensi penggunaan auto scaner barcode (P5)

$$
\begin{aligned}
& r_{x y}=\frac{n \sum_{i=1}^{n} x_{i} y_{i}-\sum_{i=1}^{n} x_{i} \sum_{i=1}^{n} y_{i}}{\sqrt{\left(n \sum_{i=1}^{n} x_{i}^{2}-\left(\sum_{i=1}^{n} x_{i}\right)^{2}\right)}-\left(n \sum_{i=1}^{n} y_{i}^{2}-\left(\sum_{i=1}^{n} y_{i}\right)^{2}\right)} \\
& r_{x y}=\frac{(10 \times 1190)-(394)(394)}{\sqrt{\left(10 \times 118-\left(34^{2}\right)\right)\left(10 \times 12189-\left(349^{2}\right)\right)}}=\frac{(11900)-(11866)}{\sqrt{(1180-1156)(121890-121801)}} \\
& r_{x y}=\frac{34}{\sqrt{(24)(89)}}=\frac{34}{\sqrt{(2136)}}=\frac{34}{46,217}=0,7357
\end{aligned}
$$

Dalam pengambilan keputusan, maka butir pertanyaan dikatakan valid jika nilai $r$ hitung $>r$ table, dapat dilihat di output contoh perhitungan pengujian validitas $P 5$, yaitu nilai $r$ hitung $0,7357>r$ table 0,6319 , dimana untuk nilai $r$ tabel digunakan rumus derajat kebebasan yaitu $n-2(a=0,05$ atau $5 \%)$ dengan uji 2 sisi dan $n=10$ maka titik kritisnya adalah 0,6319 dan $n$ adalah jumlah responden. Dilihat dari perhitungan tersebut untuk butir-butir pertanyaan yang diajukan ke responden (operator), dimana butir-butir pertanyaan yang mewakili aktifitas implementasi pengecekan auto scaner barcode dinyatakan valid (konsisten dan efektif).

2. Perhitungan reliabilitas 
Untuk uji reliabilitas dapat dilihat pada nilai Cronbach's Alpha dimana jika nila alpha $>0,60$ maka butir pertanyaan tersebut dinyatakan reliabel. Jika reliabel maka pertanyaan tersebut bisa dihilangkan atau diganti dengan pertanyaan lain. Reliabilitas dapat diukur dengan jalan mengulang pertanyaan yang mirip pada nomor-nomor berikutnya, atau dengan jalan melihat konsistensinya (diukur dengan korelasi) dengan pertanyaan lain. Berikut ini adalah contoh perhitungan reliabilitas konsisitensi penggunaan auto scaner barcode (P10) seperti pada Tabel 5.

Tabel 5. Contoh Reliabilitas P10

\begin{tabular}{|c|c|c|c|}
\hline NO & (OP) & $\begin{array}{l}\text { P10 } \\
(X)\end{array}$ & $\mathrm{P}^{2}$ \\
\hline 1 & OP1 & 4 & 16 \\
\hline 2 & OP2 & 4 & 16 \\
\hline 3 & $\mathrm{OP} 3$ & 3 & 9 \\
\hline 4 & $\mathrm{OP} 4$ & 2 & 4 \\
\hline 5 & OP5 & 4 & 16 \\
\hline 6 & OP6 & 3 & 9 \\
\hline 7 & OP7 & 4 & 16 \\
\hline 8 & OP8 & 2 & 4 \\
\hline 9 & $\mathrm{OPg}$ & 4 & 16 \\
\hline 10 & OP10 & 3 & 9 \\
\hline \multicolumn{2}{|c|}{ TOTAL } & 33 & 115 \\
\hline
\end{tabular}

Berikut ini adalah contoh perhitungan reliabilitas konsisitensi penggunaan auto scaner barcode (P10):

$$
\begin{aligned}
& S^{2}=\frac{n \sum x^{2}-\left(\sum x\right)^{2}}{n(n-1)} \\
& S^{2} P 10=\frac{10 \times 115-(33)^{2}}{10(9)}=\frac{1150-(1089)}{90}=\frac{61}{90}=0,6778
\end{aligned}
$$

Dapat dilihat dari Tabel 5 dan perhitungan reliabilitas konsisitensi penggunaan auto scaner barcode (P10), bahwa untuk point kuisioner dapat memisahkan barcode yang No Good (NG) Secara Otomatis adalah valid $r$ hitung 0,6778 lebih besar dari $r$ table 0,6319. Berikut ini adalah contoh Tabel 6 dan perhitungan reliabilitas konsisitensi penggunaan auto scaner barcode (Ptotal):

\begin{tabular}{|c|c|c|c|}
\hline NO & (OP) & $\begin{array}{l}\text { TOTAL } \\
(\mathrm{X})\end{array}$ & TOTAL² \\
\hline 1 & OP1 & 35 & 1225 \\
\hline 2 & OP2 & 34 & 1156 \\
\hline 3 & OP3 & 35 & 1225 \\
\hline 4 & OP4 & 35 & 1225 \\
\hline 5 & OP5 & 37 & 1369 \\
\hline 6 & OP6 & 35 & 1225 \\
\hline NO & (OP) & $\begin{array}{l}\text { TOTAL } \\
(\mathrm{X})\end{array}$ & TOTAL² \\
\hline 7 & OP7 & 34 & 1156 \\
\hline 8 & OP8 & 34 & 1156 \\
\hline 9 & OP9 & 36 & 1296 \\
\hline 10 & OP10 & 34 & 1156 \\
\hline \multicolumn{2}{|c|}{ TOTAL } & 349 & 12189 \\
\hline
\end{tabular}

Tabel 6. Contoh Reliabilitas Ptotal

Perhitungan reliabilitas konsisitensi penggunaan auto scaner barcode (Ptotal): 


$$
\begin{aligned}
& S^{2} \text { PTotal }=\frac{n \sum x^{2}-\left(\sum x\right)^{2}}{n(n-1)} \\
& S^{2} \text { PTotal }=\frac{10 \times 12189-(349)^{2}}{10(9)}=\frac{121890-121801}{90}=\frac{89}{90}=0,989
\end{aligned}
$$

Maka perhitungan $\Sigma s^{2} p=$ Total dari varian butir kuisioner/pernyataan dan CrAlpha adalah:

$\mathrm{s}^{2} \mathrm{p} 1=0,1$

$\mathrm{s}^{2} \mathrm{p} 2=0,233333333$

$\mathrm{s}^{2} \mathrm{p} 3=0,488888889$

$\mathrm{s}^{2} \mathrm{p} 4=0,177777778$

$s^{2} \mathrm{p} 5=0,488888889$

$s^{2} p 6=0,455555556$

$s^{2} \mathrm{p} 7=0,277777778$

$s^{2} \mathrm{p} 8=0,622222222$

$s^{2} \mathrm{p} 9=0,177777778$

$\underline{s^{2} p 10=0,677777778}$

$\mathrm{s}^{2} \mathrm{p}=\Sigma=\quad 3,7$

Perhitungan CrAlpha: ${ }^{2}$ Total $=0,989$

$$
\begin{aligned}
& \text { CrAlpha }=\left(\frac{k}{k-1}\right)\left(1-\frac{\sum s^{2} p}{s^{2} t}\right) \\
& \text { CrAlpha }=\left(\frac{10}{10-1}\right)\left(1-\frac{3,7}{0,989}\right)=\left(\frac{10}{9}\right)(3,7412) \\
& \text { CrAlpha }=(1,111)(3,7412)=4,157
\end{aligned}
$$
1,00

Dilihat dari perhitungan pada nilai reliabilitas diatas dapat disimpulkan bahwa nilai CrAlfa adalah 4,157 lebih besar dari

\section{KESIMPULAN}

Berdasarkan hasil data trial dan penelitian pada implementasi auto scaner barcode, serta pengujian kenyamanan dan ke efektifitasan karyawan dalam menjalankan hasil perbaikan untuk pengecekan barcode pada Inner Box secara otomatis di PT. Duta Nichirindo Pratama line assembling production, maka didapatkan beberapa kesimpulan sebagai berikut:

1. Pengecekan barcode secara otomatis yang menggunakan sistem komputasi, dilihat dari hasil trial berjalan dengan efektif yang disesuaikan dengan kebutuhan proses produksi seperti: scaner barcode dapat mengetahui kesalahan pada label barcode, scaner barcode dapat memunculkan master barang dan memunculkan Stock Barang, scaner barcode dapat memunculkan laporan dan menampilkan Qty, scaner barcode dapat memberikan tanda peringatan apabila ada kesalahan barcode, scaner barcode dapat membaca barcode dengan cepat, scaner barcode dapat mengindentifikasi kode barcode, scaner barcode dapat menampilkan jumlah produksi yang $O K$, scaner barcode dapat menampilkan jumlah produksi yang No Good (NG), scaner barcode dapat mengurangi kesalahan pada barcode box, dan scaner barcode dapat memisahkan barcode yang No Good (NG).

2. Hasil pengujian pada hasil kuisioner yang telah diisi oleh operator dengan menggunakan perhitungan validitas, menunjukan bahwa hasil perbaikan pembuatan dan perancangan auto scaner barcode pada inner box sangat efektif dan konsisten dijalankam oleh operator rata-rata dari pengisian kuisioner adalah 3 (tiga) atau setuju, dapat dilihat dari hasil pengujian validitas adalah nilai $r$ hitung lebih besar dari $r$ table adalah sebagai berikut seperti Tabel 7 . 
Tabel 7. Penarikan Kesimpulan Uji Validitas

\begin{tabular}{cccc}
\hline Variabel & R Hitung & R Tabel & Keterangan \\
\hline P1 & 0,100 & & Tidak Valid \\
P2 & 0,233 & & Tidak Valid \\
P3 & 0,489 & & Tidak Valid \\
P4 & 0,178 & & Tidak Valid \\
P5 & 0,489 & \multirow{2}{*}{, 6319} & Tidak Valid \\
P6 & 0,456 & & Tidak Valid \\
P7 & 0,278 & & Tidak Valid \\
P8 & 0,622 & & Tidak Valid \\
P9 & 0,178 & & Tidak Valid \\
P10 & 0,678 & & Valid \\
\hline
\end{tabular}

pada tabel diatas menunjukan bahwa untuk point kuisioner Dapat Memisahkan Barcode yang No Good (NG) Secara Otomatis adalah valid, $r$ hitung 0,678 lebih besar dari $r$ table 0,6319 dan untuk point 1 (satu) sampai dengan 9 (sembilan) tidak valid, namun point point 1 (satu) sampai dengan sembilan dirangkum pada point 10 (sepuluh).

3. Hasil pengujian reliability adalah nilai Cronbach's Alpha (nila alpha) dilihat dari standard perhitungan pada nilai kategori koefisien reliabilitas, dapat disimpulkan bahwa nilai CrAlfa 4,157 lebih besar dari 1,00 dan rata-rata dari hasil pengisian kuisioner adalah skor 3 atau bisa disebut Setuju pada hasil perancangan dan pembuatan auto scaner barcode tersebut. Jadi implementasi pengecekan sistem auto scaner barcode dinyatakan efektif/konsisten (sangat reliabiliti).

\section{DAFTAR PUSTAKA}

[1] Darian Wiraguna. "Relevansi Pengalaman Praktik Kerja Industri Terhadap Kesiapan Peserta Didik Teknik Otomasi Industri SMKN 1 Cimahi Dalam Memasuki Dunia Kerja”. Universitas Pendidikan Indonesia: repository.upi.edu, perpustakaan.upi.edu. 2017.

[2] Sahid Raharjo. (2019) "Cara Membaca Distribusi Nilai r Tabel Product Moment Lengkap". Universitas Muhamaddiyah Malang. [Online]. Available https://www.spssindonesia.com/2019/01/cara-membacanilai-r-tabel-product-moment.html.

[3] Ambar Kusuma A, Yuli S. "Fakultas Bisnis, Universitas Kristen Duta Wacana", "Pemodelan Group Berdasarkan Gendre Pada Perilaku Konsumen Lo Cost Green Car (LCGC)”. Jurnal Bisnis Managemen. Vol. 12 No.3 ISSN 1411-9366, 2016.

[4] Darma Setiawan. (2017). Prototipe Sistem Otomatisasi Pintu Pagar Berbasis Mikrokontroler Arduino Uno R3 Via Bluetooth Android. APK. Fakultas Teknik Universitas Lampung. [Online]. Available https://www.coursehero.com/file/51399278/SKRIPSI-3pdf/

[5] Dyah Budiastuti, Agustinus Bandur. "Validitas Dan Reliabilitas Penelitian". Bogor: Mitra Media Wacana. 2018

[6] Putra Yudha, I. P. A, Sudarma M \& Arya Mertasana P. "Perancangan Aplikasi Sistem Inventory Barang Menggunakan Barcode Scanner Berbasis Android". Jurnal SPEKTRUM, 4(2), 72, 2018.

[7] Raden Welly Trijatno Putro. "Aplikasi Pendeteksi Kesalahan Barcode Pada Box PT. DNP", STMIK Bina Sarana Global Tangerang, 2015.

[8] Sugiarti Y. "Analisis dan Perancangan UML (Unefied Modelling Language) Generated VB.6. Analisis Dan Perancangan UML, 138", 2015.

[9] Sujarweni, Wiratna. "Pengujian Validitas dan Reliabilitas". Yogyakarta: Pustaka Baru Press. 2015. 